\title{
Characterization of Peptostreptococcus asaccharolyticus Glutamate Dehydrogenase Purified by Dye-ligand Chromatography
}

\author{
By DAVID P. HORNBY AND PAUL C. ENGEL* \\ Department of Biochemistry, University of Sheffield, Western Bank, Sheffield S10 2TN, UK
}

(Received 2 March 1984; revised 9 April 1984)

\begin{abstract}
Glutamate dehydrogenase (L-glutamate: $\mathrm{NAD}^{+}$oxidoreductase (deaminating); EC 1.4.1.2) has been purified from Peptostreptococcus asaccharolyticus in a single step using dye-ligand chromatography. The enzyme (GDH) was present in high yields and was stabilized in crude extracts. A subunit molecular weight of $49000 \pm 500$ was determined by SDS polyacrylamide gel electrophoresis and six bands were obtained after cross-linking the subunits with dimethyl suberimidate. This bacterial GDH was predominantly $\mathrm{NAD}^{+}$-linked, but was able to utilize both $\mathrm{NADP}^{+}$and NADPH at $4 \%$ of the rates with $\mathrm{NAD}^{+}$and NADH, respectively. An investigation of the amino acid specificity revealed some similarities with GDH from mammalian sources and some clear differences. The values of apparent $K_{\mathrm{m}}$ for the substrates ammonia, 2-oxoglutarate, NADH, $\mathrm{NAD}^{+}$and glutamate were 18.4,0.82,0.066, 0.031 and $6 \mathrm{mM}$, respectively. The $P$. asaccharolyticus GDH was not regulated by purine nucleotides, but was subject to strong inhibition with increasing ionic strength.
\end{abstract}

\section{INTRODUCTION}

Glutamate dehydrogenase (GDH) has been purified from Peptostreptococcus asaccharolyticus (formerly called Peptococcus aerogenes and Micrococcus aerogenes) by three independent groups (Kew \& Woolfolk, 1970; Johnson \& Westlake, 1972b; Lerud \& Whiteley, 1971). In all three cases the enzyme was reported to be present in high levels in cell-free extracts, but yields of pure enzyme were relatively low. The enzyme catalyses the first step in the fermentation of glutamate via the hydroxyglutarate pathway (Johnson \& Westlake, 1972a). It operates in the direction of oxidative deamination, providing 2-oxoglutarate for subsequent reduction by 2-oxoglutarate reductase. Buckel \& Barker (1974) have subsequently identified the pathway in a number of other anaerobes; all are characterized by the presence of these two enzymes.

The hydroxyglutarate pathway is one of two main routes for glutamate fermentation in anaerobic bacteria (see Barker, 1981); the other is the citramalate pathway (e.g. Barker, 1961) characterized by the presence of the enzyme $\beta$-methyl aspartase (Buckel $\&$ Barker, 1974), and a different distribution in the fermentation product, butyrate, of the carbon atoms derived from glutamate (Horler et al., 1966a, b; Buckel, 1980). Studies of $P$. asaccharolyticus and Acidaminococcus fermentans (Buckel, 1980) have led to the elucidation of the hydroxyglutarate pathway.

This particular GDH has been partially characterized (Johnson \& Westlake, 1972 $b$; Kew \& Woolfolk, 1970) and seems to be predominantly NAD+-linked. It has, however, been claimed to be able also to utilize NADPH but not NADP ${ }^{+}$(Kew \& Woolfolk, 1970). This unusual finding requires clarification. In this paper we report the purification of $P$. asaccharolyticus GDH by a single-step method employing dye-ligand chromatography, and the characterization of the

Abbreviation: GDH, glutamate dehydrogenase. 
enzyme with respect to its subunit structure and basic kinetic properties. We have also overcome the problems of GDH instability in crude extracts reported by Kew \& Woolfolk (1970).

\section{METHODS}

Materials. The reagents and media used are given below with the appropriate supplier in parentheses. Yeast extract, agar and bacterial peptone (Oxoid); monosodium L-glutamate, acrylamide and imidazole (Koch-Light); biotin, dimethyl suberimidate, norvaline, ovalbumin, $\dot{2}$-oxoglutaric acid, bovine serum albumin, hen egg-white lysozyme, $\beta$-lactoglobulin and trypsinogen (Sigma); all other enzymes and proteins (Biozyme); cofactors and nucleotides (Boehringer); with the exception of Biogel P2 (Bio-Rad) all column materials were obtained from Pharmacia.

The triazine dyes used in screening experiments were gifts from Dr C. V. Stead (ICI Dyestuffs Division, Manchester, UK) and were linked to Sepharose 6B according to the method of Dean \& Watson (1979). DL- $\beta$ methylglutamate was a gift from Dr S. Ghisla (University of Konstanz, FRG) whilst all other glutamate analogues were gifts from Dr S.-I. Hatanaka (College of General Education, University of Tokyo, Japan). All other reagents were AnalaR grade from BDH.

Growth and extraction of bacteria. Cultures of $P$. asaccharolyticus were obtained from the American Type Culture Collection (ATCC 14963) and as a gift from Dr W. Buckel (University of Regensburg, FRG). The growth medium contained $0.4 \%$ yeast extract, $0.1 \% \mathrm{NaCl}, 0.4 \%$ potassium diphosphate, $0.02 \%$ ascorbic acid, $1 \%$ monosodium Lglutamate (all w/v) and $100 \mu \mathrm{g}$ biotin $1^{-1}$. Peptone $(0.1 \%, \mathrm{w} / \mathrm{v})$ and agar $(0.2 \%, \mathrm{w} / \mathrm{v})$ were only included in tube cultures. This 'Biotin' medium differs from that of Whiteley (1957), which is normally used to cultivate $P$. asaccharolyticus, and gave higher cell yields. The 'Biotin' medium induced high levels of GDH and, when peptone was excluded (in large-volume cultures) activity in crude extracts frozen in $20 \mathrm{mM}$-potassium phosphate, $\mathrm{pH} 7$, remained stable for a year. These modifications to the medium, notably the presence of biotin (W. Buckel, personal communication) and the exclusion of peptone, alleviated earlier problems of instability. Peptone, however, was necessary in subcultures, for long-term maintenance of GDH activity.

Cells were grown in 40 litre batches at $37^{\circ} \mathrm{C}$ and $\mathrm{pH} 7$, and were harvested and washed in $0.1 \mathrm{M}$-potassium phosphate buffer, $\mathrm{pH} \mathrm{7}$, containing $0.02 \%$ (w/v) ascorbic acid. A typical yield from this volume was $100 \mathrm{~g}$ (wet wt) of packed cells. Cell breakage was effected either by $30 \mathrm{~min}$ sonication of a $1: 1$ cell suspension in $20 \mathrm{~mm}$-potassium phosphate buffer, $\mathrm{pH} 7$, using a Heat Systems sonifier, or by grinding mechanically in a steel ball-mill, manufactured in the departmental workshop. The cell-free extract was obtained after centrifugation for $1 \mathrm{~h}$ at $27000 \mathrm{~g}$ on a Sorvall RC5 centrifuge.

Purification of P. asaccharolyticus GDH. GDH activity was monitored by the method of Johnson \& Westlake $(1972 b)$, and the units $(\mathrm{U})$ are expressed as $\mu \mathrm{mol} \mathrm{NADH} \min ^{-1}$. The routine assay mixture contained $10 \mathrm{mM}-\mathrm{L}$ glutamate and $1 \mathrm{~mm}-\mathrm{NAD}^{+}$in $40 \mathrm{~mm}-\mathrm{Tris} / \mathrm{HCl}, \mathrm{pH} 8.8$. Protein was determined by the method of Bradford (1976), with ox-liver GDH as a standard. All assays were performed on a recording fluorimeter similar to that described by Engel \& Dalziel (1969). This instrument is designed to give high sensitivity and stability, together with a facility for 'backing off' a large part of the signal by using a variable voltage in opposition. Since reduced coenzyme is the only compound that changes in concentration during reaction, the instrument has a wide bandpass filter (maximum transmission at $450 \mathrm{~nm}$ ) rather than any more sophisticated means of obtaining monochromatic light. The high sensitivity of such instruments, even when compared with modern spectrophotometers, makes it possible to follow accurately very small $\mathrm{NAD}(\mathrm{P}) \mathrm{H}$ concentration changes, so that rate measurements can be made confidently from the early, linear part of the progress curve.

All commercial column materials were prepared according to the manufacturers' instructions and were run under the conditions specified. Triazine dye columns were equilibrated in $20 \mathrm{mM}$-potassium phosphate, $\mathrm{pH} 7$, containing $0.02 \%(\mathrm{w} / \mathrm{v})$ sodium azide and were developed at room temperature. After each run the columns were washed with a column volume of $6 \mathrm{M}$-urea and re-equilibrated in the starting buffer.

The general procedure for screening was that used by Hey \& Dean (1981). However, no negative step, in which the desired product passes through the column, whilst impurities are retained, was found with the dyes tested. For some experiments, notably the determination of coenzyme specificity, GDH was purified by the method of Hornby \& Engel (1983), which includes a heat step similar to that of Kew \& Woolfolk (1970).

Gel electrophoresis. Non-SDS gels $(7.5 \%$, w/v) were prepared according to the method of Davies (1964) and were used for activity and protein staining. The GDH activity stain comprised: $1 \mathrm{mM}-\mathrm{NAD}^{+}, 40 \mathrm{mM}$-glutamate, $1 \mathrm{mg}$ nitroviolet tetrazolium $\mathrm{ml}^{-1}$ (Sigma) and $2 \mu \mathrm{g}$ Meldolablue $\mathrm{ml}^{-1}$ in $40 \mathrm{~mm}-\mathrm{Tris} / \mathrm{HCl}, \mathrm{pH} 8.8$, at $37^{\circ} \mathrm{C}$. The same mixture, but with 2-hydroxyglutarate in place of glutamate, could be used for detecting 2-oxoglutarate reductase in crude cell extracts.

The subunit molecular weight of the bacterial GDH was determined from a series of SDS gels, prepared according to the method of Laemmli (1970). Each gel was calibrated with the following proteins: ovalbumin (mol. wt 45000), bovine serum albumin (66000), alkaline phosphatase (67000), ox-liver GDH (56000), yeast glucose-6phosphate dehydrogenase (51000), hog renal acylase (48000), yeast alcohol dehydrogenase (40000), bacterial 
butyryl-CoA dehydrogenase (39000, a gift from Dr G. Williamson of this Department), pig heart lactate dehydrogenase (35000), trypsinogen (24000), $\beta$-lactoglobulin (18400) and hen egg-white lysozyme (14400). Gels were made up to 10,12 , and $15 \%$ and the mean result of three experiments was taken as the best estimate.

The subunit structure of $P$. asaccharolyticus GDH was determined by cross-linking with the bifunctional reagent dimethyl suberimidate. In two parallel experiments the bacterial enzyme and ox-liver GDH were cross-linked simultaneously in order to compare structures. The procedure which gave the best banding pattern was as follows. Both GDHs at a concentration of $1 \mathrm{mg} \mathrm{ml}^{-1}$ were dialysed against 1 litre of $200 \mathrm{mM}$-sodium borate $\mathrm{pH} 9 ; 0 \cdot 1 \mathrm{ml}$ of a freshly prepared solution of $20 \mathrm{mg}$ dimethyl suberimidate $\mathrm{ml}^{-1}$ was then added to each sample and the two mixtures were incubated at room temperature for $3 \mathrm{~h}$. Excess dimethyl suberimidate was subsequently removed by dialysis against distilled water, and the samples were freeze-dried. The residual white powders were re-dissolved in the SDS sample additive containing $1 \%$ SDS, $2 \%$ mercaptoethanol, $0 \cdot 1 \%$ bromophenol blue and $20 \%$ sucrose (all $\mathrm{w} / \mathrm{v}$ ), and were boiled for $5 \mathrm{~min}$. The final protein concentration was $2 \mathrm{mg} \mathrm{ml}^{-1}$ in each case, and $30 \mu \mathrm{l}$ of each sample was loaded and run on $3 \%$ rod gels as described by Thomas (1978). The gels were subsequently stained with Coomassie blue in a mixture of methanol/water/acetic acid $(5: 5: 1$, by vol.) and destained in water/methanol/ acetic acid $(16: 2: 1$, by vol.) in the presence of activated charcoal.

\section{RESULTS}

\section{Growth of $P$. asaccharolyticus}

During growth of this anaerobe over $26 \mathrm{~h}$, stationary phase was reached after about $10 \mathrm{~h}$ and GDH levels reached a sharp maximum after $24 \mathrm{~h}$ (Fig. 1) - this was somewhat surprising in view of the dependence of energy production upon glutamate fermentation. Cells were therefore harvested routinely after $24 \mathrm{~h}$ growth.

\section{Purification of GDH from P. asaccharolyticus}

Initially the low yields obtained by earlier workers were improved upon by combining the most successful of the published purification steps and incorporating the use of a Blue Sepharose column. The resulting four-step procedure, hereafter referred to as Method I, gave a $55 \%$ yield of pure enzyme (Hornby \& Engel, 1983). Subsequently we examined the possibility of developing a single-step purification by using dye-ligand chromatography. An overall purification of around 10 -fold is required in view of the very high starting levels of GDH in the crude extract. Dyes linked to Sepharose 6B were used to screen the crude extract (Table 1).

With the exception of Procion Brown MX-5BR, all of the dyes showed some affinity for the GDH. The three dyes chosen for further study were Procion Blue PGR, Orange MX-G and Red $\mathrm{MX}-5 \mathrm{~B}$; all gave approximately six-fold purification by simple salt elution in a single $1 \mathrm{M}-\mathrm{NaCl}$

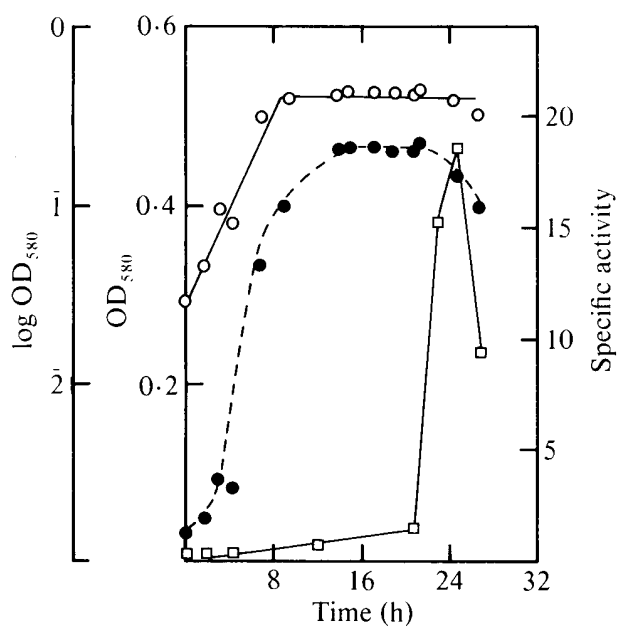

Fig. 1. Growth curve for $P$. asaccharolyticus grown on the 'Biotin' medium and the specific activity of glutamate dehydrogenase. - Growth $\left(\mathrm{OD}_{580}\right) ; \bigcirc, \log \mathrm{OD}_{580} ; \square$, activity of GDH (arbitrary units). 


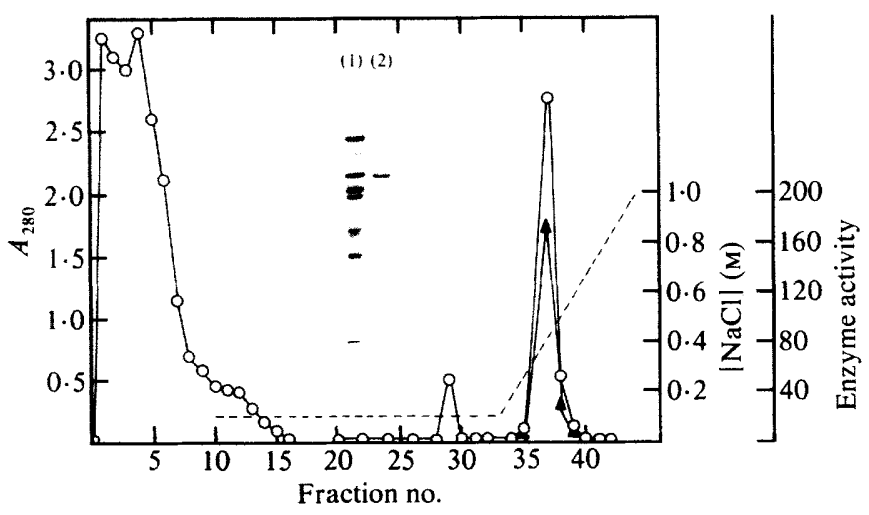

Fig. 2. Elution of GDH from Procion Blue PGR-linked Sepharose 6B. Activity ( $\boldsymbol{\Delta}$; arbitrary units) was detected after the column $(7 \times 7 \mathrm{~cm})$ was developed with a $100 \mathrm{~mm}-\mathrm{NaCl}$ wash and a $\mathrm{pH}$ gradient from 6 to 9 followed by a salt gradient (broken line) up to $1 \mathrm{M}-\mathrm{NaCl}$. The $A_{280}$ measurements $(O)$ are also shown. The inset shows an SDS gel of (1) crude extract and (2) the purified product; in both cases $10 \mu \mathrm{g}$ protein was loaded.

\section{Table 1. Purification of $P$. asaccharolyticus $G D H$ on dye-linked columns}

A $5 \mathrm{ml} \mathrm{sample} \mathrm{of} \mathrm{crude} \mathrm{extract} \mathrm{of} P$. asaccharolyticus was loaded onto a $10 \mathrm{ml}$ column of the composition indicated. The columns were washed with 2 vols $20 \mathrm{~mm}$-potassium phosphate, $\mathrm{pH} 7$, followed by elution with $20 \mathrm{ml} 1 \mathrm{M}-\mathrm{NaCl}$. The activity was determined as described in Methods, and protein was estimated by the method of Bradford (1976).

$\begin{array}{lcc}\begin{array}{c}\text { Sepharose-linked } \\ \text { Procion dye }\end{array} & \begin{array}{c}\text { Specific activity } \\ \text { after elution } \\ \left(\mu \mathrm{mol} \mathrm{min}^{-1} \mathrm{mg}^{-1}\right)\end{array} & \begin{array}{c}\text { Purification } \\ \text { factor }\end{array} \\ \text { Blue MX-3G } & 3 \cdot 8 & 2 \cdot 7 \\ \text { Blue MX-R } & 5 \cdot 2 & 3 \cdot 7 \\ \text { Blue PGR } & 8 \cdot 4 & 6 \\ \text { Orange MX-2R } & 2 \cdot 9 & 2 \cdot 1 \\ \text { Orange MX-G } & 7 \cdot 9 & 5 \cdot 6 \\ \text { Red MX-5B } & 8 \cdot 2 & 5 \cdot 9 \\ \text { Red HE-3B } & 3 \cdot 7 & 2 \cdot 6 \\ \text { Green HE-4BD } & 4 \cdot 1 & 3 \\ \text { Brown MX-5BR } & -- & -\end{array}$

wash. The elution profile in Fig. 2 shows how first a pH gradient, 6-9, and then a salt gradient, $0-1 \mathrm{M}-\mathrm{NaCl}$ in $20 \mathrm{mM}$-potassium phosphate, $\mathrm{pH} 7$, resolved $\mathrm{GDH}$ from the other proteins on Procion Blue PGR-linked Sepharose 6B. The $\mathrm{pH}$ gradient was created using two buffers of constant ionic strength containing $0 \cdot 2 \mathrm{M}$-potassium phosphate $/ 0 \cdot 1 \mathrm{M}$-glycine, adjusted to the appropriate $\mathrm{pH}$ with either $1 \mathrm{M}-\mathrm{HCl}$ or $1 \mathrm{M}-\mathrm{KOH}$. This procedure is referred to as Method II (see Fig. 2). The GDH purified in this way had a specific activity of $13.8 \mathrm{U} \mathrm{mg}^{-1}$ and gave a single band on SDS-PAGE. Similar results were obtained with Orange MX-G and Red MX-5B columns, and compare favourably with those from Method I, but with yields of more than $80 \%$.

\section{Characterization of $P$. asaccharolyticus $G D H$}

Kew \& Woolfolk (1970) and Johnson \& Westlake (1972b) have both reported that this GDH can utilize $\mathrm{NAD}^{+}, \mathrm{NADH}$ and NADPH but surprisingly not $\mathrm{NADP}^{+}$. The coenzyme specificity of $P$. asaccharolyticus GDH was therefore examined using highly purified coenzyme preparations. The four coenzymes were purified on DEAE-Sephadex A25, essentially according to the method of Dickinson \& Engel (1977) and used within a few weeks of purification.

At pH 7 in $0 \cdot 1 \mathrm{M}$-potassium phosphate, GDH was able to utilize both NADP ${ }^{+}$and NADPH at $4 \%$ of the rate obtained when $\mathrm{NAD}^{+}$and NADH were the coenzymes, respectively. In the 


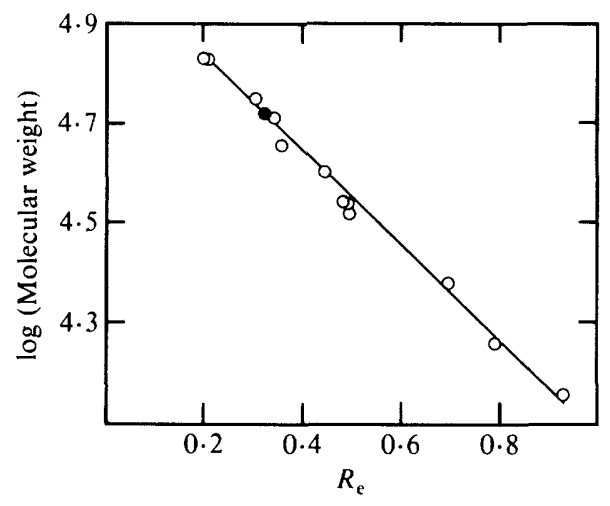

Fig. 3. Subunit molecular weight of $P$. asaccharolyticus GDH $(\odot)$ as determined by SDS-PAGE on a $10 \%$ gel using the molecular weight standards $(O)$ listed in Methods. The mean estimate from three such gels (at different acrylamide concentrations) was $49000 \pm 500$.

assays with oxidized coenzymes (at $82 \mu \mathrm{M}$ ) the glutamate concentration was $40 \mathrm{mM}$, whilst with the reduced coenzymes (at $64 \mu \mathrm{M}$ ) the substrate concentrations were: 2-oxoglutarate, $5 \mathrm{mM}$ and $\mathrm{NH}_{4} \mathrm{Cl}, 50 \mathrm{~mm}$. The demonstration of activity with $\mathrm{NADP}^{+}$is in contrast to the results of Kew \& Woolfolk (1970) who could detect no NADP ${ }^{+}$-linked activity at both $\mathrm{pH} 7.0$ and $\mathrm{pH} \mathrm{8.5.} \mathrm{The}$ possibility of $\mathrm{NADP}^{+}$being contaminated with $\mathrm{NAD}^{+}$in these experiments was ruled out since the two coenzymes are readily separated by the above purification procedure.

Kew \& Woolfolk (1970) also reported the presence of a separate NADP+-linked GDH which differed from the NAD ${ }^{+}$-linked enzyme in terms of both molecular weight and thermostability. The enzyme used in our specificity study was prepared by Method I, which includes a heat step that would be expected to remove the separate NADP ${ }^{+}$-linked enzyme (Kew \& Woolfolk, 1970). Nevertheless, to test further whether the NADP ${ }^{+}$-linked activity in our preparation was an intrinsic property of the $\mathrm{NAD}^{+}$-linked GDH or due to a contaminant, the enzyme was rechromatographed on Sephacryl S-400, and the specific activity of eluted fractions was determined with both $\mathrm{NAD}^{+}$and $\mathrm{NADP}^{+}$. The ratio of activities remained essentially constant across the peak, implying that a single GDH species was present.

When non-SDS gels were run with the purified GDH, and stained for both $\mathrm{NAD}^{+}-$and $\mathrm{NADP}^{+}$-linked activity at $\mathrm{pH} 8 \cdot 8$, no $\mathrm{NADP}^{+}-$-linked $\mathrm{GDH}$ activity could be detected. Since Kew \& Woolfolk (1970) were unable to detect NADP ${ }^{+}$-linked activity in $20 \mathrm{~mm}$-Tris at pH 8.5 , the observations made here would seem to imply that in phosphate at $\mathrm{pH} 7$ the activity towards $\mathrm{NADP}^{+}$is measurable whilst in Tris it is not. Hence the differences in assay conditions may explain the discrepancy between these two investigations. Under the appropriate assay conditions, the predominantly $\mathrm{NAD}^{+}$-linked GDH of $P$. asaccharolyticus can utilize $\mathrm{NADP}^{+}$as coenzyme.

\section{Quaternary structure and subunit molecular weight of $P$. asaccharolyticus $G D H$}

With the exception of the tetrameric, fungal GDHs which are $\mathrm{NAD}^{+}$-linked and have subunit molecular weights around 116000 (Smith et al., 1975), GDHs generally have subunit molecular weights of between 45000 and 60000 , with the bacterial enzymes falling at the bottom end of this range.

The subunit molecular weight of $P$. asaccharolyticus GDH has not previously been determined, but the native enzyme has a molecular weight of about 266000 , estimated from gel filtration and analytical ultracentrifugation studies (Johnson \& Westlake, 1972b). Comparison of the mobility of GDH and various marker proteins on SDS gels yielded a subunit molecular weight of $49000 \pm 500$ (Fig. 3), suggesting that this GDH is either a pentamer or a hexamer. The latter result seems more plausible in view of the common occurrence of hexameric GDHs.

Fig. 4 shows the banding pattern for GDH, cross-linked with dimethyl suberimidate, as a densitometric gel-scan. There are clearly six major bands, together with a higher molecular 


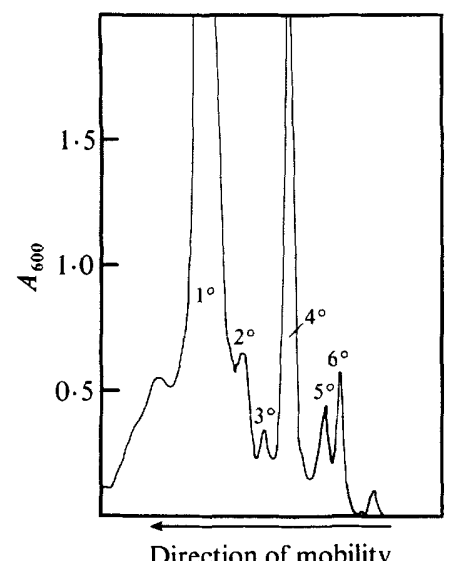

Fig. 4

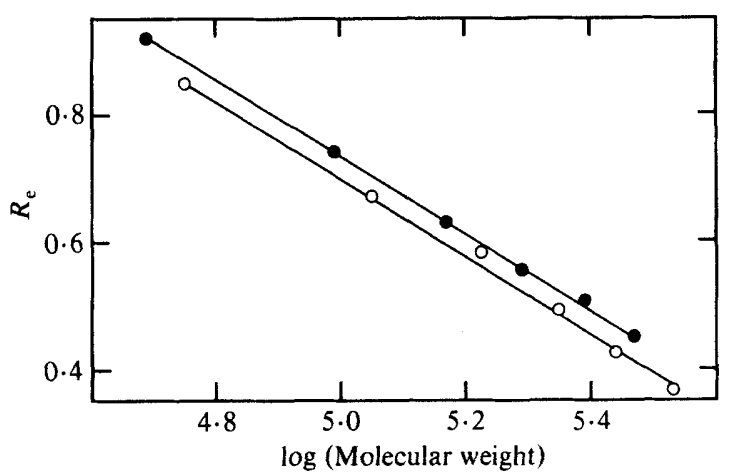

Fig. 5

Fig. 4. Densitometric scan of a stained gel after electrophoresis of cross-linked $P$. asaccharolyticus $\mathrm{GDH}$ on a $3 \% \mathrm{gel}$ in the presence of SDS.

Fig. 5. Plot of the mobilities of the six GDH species from Fig. 4, showing the linear dependence of mobility on log molecular weight, assuming a subunit molecular weight of 49000 and a hexameric structure (O). The open circles are the analogous results obtained with ox-liver GDH.

\section{Table 2. Preliminary kinetic data for P. asaccharolyticus GDH at pH 7 in $0 \cdot 1 \mathrm{M}$-potassium} phosphate buffer at $25^{\circ} \mathrm{C}$

The fixed concentrations of other reactants were, where appropriate, $40 \mathrm{~mm}$-L-glutamate or $1 \mathrm{~mm}$ $\mathrm{NAD}^{+}$for the oxidative deamination reaction and $400 \mu \mathrm{M}$-2-oxoglutarate, $50 \mathrm{mM}-\mathrm{NH}_{4} \mathrm{Cl}$ and $200 \mu \mathrm{M}$ $\mathrm{NADH}$ for the reductive amination.

\begin{tabular}{lcc}
\multicolumn{1}{c}{ Substrate } & $\begin{array}{c}\text { Concn range } \\
\text { tested }(\mu \mathrm{M})\end{array}$ & $K_{\mathrm{m}}$ \\
$\mathrm{NAD}^{+}$ & $1-4 \times 10^{3}$ & $31 \mu \mathrm{M}$ \\
Glutamate & $10^{3}-200 \times 10^{3}$ & $6.6 \mathrm{mM}$ \\
NADH & $5-2 \times 10^{3}$ & $66 \mu \mathrm{M}$ \\
2-Oxoglutarate & $150-450$ & $0.82 \mathrm{mM}$ \\
$\mathrm{NH}_{4}^{+}$ & $10^{4}-10^{6}$ & $18.4 \mathrm{mM}$
\end{tabular}

weight species. This confirms the conclusion that the bacterial GDH is hexameric. Under the conditions of the experiment shown in Fig. 4 the trimer was the least prominent of the crosslinked species, with both the bacterial and the ox-liver enzymes, a finding in contrast to the results of Hucho \& Janda (1974), who found the trimer to be a major component of the crosslinked set.

The plot of $R_{\mathrm{e}}$ vs $\log$ molecular weight of the cross-linked species (assuming a subunit molecular weight of 49000 for the bacterial enzyme) was completely linear for both enzymes (Fig. 5). The plot only deviated from linearity when the acrylamide concentration was raised significantly above $3 \%$.

\section{Kinetic properties of $P$. asaccharolyticus $G D H$}

The apparent $K_{\mathrm{m}}$ values for all five substrates were determined in $0.1 \mathrm{M}$-potassium phosphate, pH 7, at $25^{\circ} \mathrm{C}$ (Table 2). The $\mathrm{NAD}^{+}$primary plot (Fig. 6) was investigated with saturating glutamate concentrations $(40 \mathrm{mM})$ over a wide range of coenzyme concentration $(1-4000 \mu \mathrm{M})$. This detailed investigation was undertaken in order to establish whether $P$. asaccharolyticus GDH shows any of the kinetic complexities seen with the mammalian GDHs. Clearly, no 'abrupt transitions' (Engel \& Dalziel, 1969) are seen over this range: the Eadie plot is perfectly linear within error. 


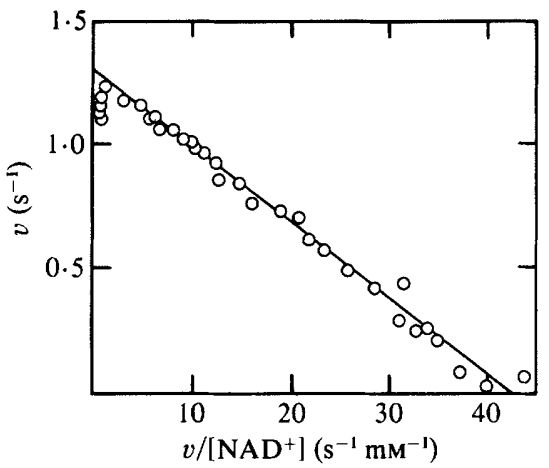

Fig. 6

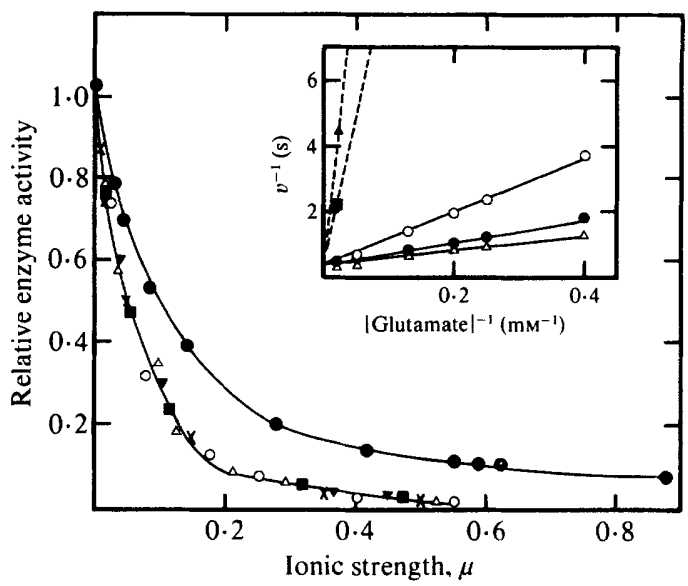

Fig. 7

Fig. 6. Eadie plot for $P$. asaccharolyticus $\mathrm{GDH}$ with $\mathrm{NAD}^{+}$concentration varied between 1 and $4000 \mu \mathrm{M}$ at $\mathrm{pH} 7$ in $0.1 \mathrm{M}$-potassium phosphate with the concentration of glutamate fixed at $40 \mathrm{~mm}$.

Fig. 7. Inhibition of $P$. asaccharolyticus GDH by a variety of ions and DL-aspartate. Main figure: $X$, $\mathrm{MgCl}_{2} ; O$, potassium phosphate; $\triangle, \mathrm{NaCl} ; \mathrm{O}, \mathrm{KCl} ; \square, \mathrm{KNO}_{3} ; \nabla, \mathrm{K}_{2} \mathrm{SO}_{4}$. The inset shows the competitive nature of the inhibition by $\mathrm{KCl}(\boldsymbol{\Lambda}, \mathbf{\square} ; \mu=0.5$ and 0.3 , respectively) and $\mathrm{DL}$-aspartate $(\boldsymbol{O}$, $O ; 10 \mathrm{mM}$ and $50 \mathrm{mM}$, respectively) as compared with the uninhibited enzyme ( $\triangle$ ). The $\mathrm{KCl}$ data in the inset are extrapolated from more detailed plots for clarity.

Similarly the plots of primary data for NADH $(5-2000 \mu \mathrm{M})$, glutamate (1-200 mM) and $\mathrm{NH}_{4} \mathrm{Cl}(10-1000 \mathrm{mM})$ were linear at saturating concentrations of 2-oxoglutarate $(400 \mu \mathrm{M})$, $\mathrm{NAD}^{+}(1 \mathrm{mM}), \mathrm{NADH}(200 \mu \mathrm{M})$, glutamate $(40 \mathrm{mM})$ and $\mathrm{NH}_{4} \mathrm{Cl}(50 \mathrm{~mm})$ where appropriate. The plot for 2-oxoglutarate under these conditions was linear up to $0.45 \mathrm{~mm}$, but non-linear above this concentration.

The amino acid specificity of GDHs has attracted considerable interest, especially that of the ox-liver enzyme (e.g. Struck \& Sizer, 1960; Hornby \& Engel, 1983). The mammalian enzymes seem to exhibit a dual specificity: thus at $\mathrm{pH} 8.5$, glutamate is oxidized optimally, whilst there is a second $\mathrm{pH}$ optimum (around 10 ) for the oxidation of a variety of monocarboxylic amino acids, including alanine and norvaline (Struck \& Sizer, 1960; Markau \& Steinhübel, 1972). The prokaryotic GDHs, although generally poorly characterized, seem not to exhibit this 'alanine' activity: a possible exception is the NADP-linked GDH from Mycobacterium smegmatis (Savada et al., 1980).

Several monocarboxylic amino acids were tested for activity together with a series of glutamate analogues retaining the correct dicarboxylate spacing (see Hornby et al., 1983). With $\mathrm{NAD}^{+}$at $1 \mathrm{~mm}$ and the amino acids all at $20 \mathrm{~mm}$, initial rates were measured at $\mathrm{pH} 7, \mathrm{pH} 8$ and pH 9 (Table 3). The relative rates of turnover indicate that there is no counterpart to the 'alanine' activity observed with ox-liver GDH, but that there is a similar discrimination among the glutamate analogues (Hornby et al., 1983). Replacement of the hydrogen atoms attached to the $\gamma$ and $\beta$ carbons with $-\mathrm{CH}_{3}$ groups results in a marked decrease in turnover. Only L- $\alpha$-amino$\gamma$-nitraminobutyrate gave a rate of turnover greater than $1 \%$ of that with glutamate. This analogue is also utilized more efficiently than the methylated analogues by ox-liver GDH (D. P. Hornby, P. C. Engel \& S.-I. Hatanaka, unpublished results).

The purine nucleotides AMP, ADP, ATP and GTP, at concentrations up to $1 \mathrm{mM}$, only slightly inhibited the activity of $P$. asaccharolyticus GDH. This inhibition was probably due to weak competition with the coenzyme. Thus $P$. asaccharolyticus GDH does not exhibit the same type of allosteric regulation as shown by ox-liver GDH and several bacterial GDHs, but could still exhibit the same type of regulation by other effectors. 
Table 3. Substrate specificity of $P$. asaccharolyticus $G D H$

Relative rates of turnover of the indicated amino acids by $P$. asaccharolyticus GDH are shown. The $100 \%$ value, for $\mathrm{L}$-glutamate at $\mathrm{pH} 7$, corresponds to a rate of $3.45 \mathrm{~s}^{-1}$. The NAD $\mathrm{N}^{+}$concentration was $250 \mu \mathrm{M}$ in each case, amino acids were fixed at $20 \mathrm{~mm}$ (or $40 \mathrm{~mm}$ for racemic mixtures) and the buffer system comprised $50 \mathrm{~mm}$-potassium phosphate $/ 50 \mathrm{~mm}$-glycine at the appropriate $\mathrm{pH}$. All rates were measured at $25^{\circ} \mathrm{C}$ with the enzyme concentration varied between 0.2 and $200 \mu \mathrm{g} \mathrm{ml}^{-1}$.

Substrate

L-Glutamate

L-threo- $\gamma$-Methylglutamate

L-erythro- $\gamma$-Methylglutamate

DL- $\beta$-Methylglutamate

$L-\gamma-$ Methyleneglutamate

L- $\alpha$-Amino- $\gamma$-nitraminobutyrate

L-Norvaline

L-Alanine

L-Leucine

$\beta$-Nitraminoalanine

DL-Glutamate

L-Aspartate

Relative rate
at $\mathrm{pH} 7$

100

$0 \cdot 61$

0.45

$0 \cdot 10$

0.04

$4 \cdot 2$

0.04

0.013

0.017

0.03

$42 \cdot 4$
Relative rate
at pH 8

209

$3 \cdot 8$

-

$18 \cdot 6$

$0 \cdot 21$

0.021

0.021

0.038

$98 \cdot 5$
Relative rate at $\mathrm{pH} 9$

965

3.5

$1 \cdot 13$

0.02

$29 \cdot 3$

$1 \cdot 22$

0.027

0.027

0.042

501

\section{The ionic strength dependence of initial rates}

The most detailed kinetic studies of GDHs have been performed with phosphate buffers (Engel \& Dalziel, 1969; Electricwala \& Dickinson, 1979). However, phosphate buffer is known to exert specific effects upon initial rates with mammalian GDHs (e.g. Engel \& Dalziel, 1969) and so the effects of various ions on the kinetic behaviour of the bacterial GDH were investigated in the hope of finding suitable conditions for detailed kinetic studies. A series of mono-, di- and trivalent ions was used, with all rates being measured in $50 \mathrm{~mm}$-imidazole buffer, $\mathrm{pH}$ 7. DL-Aspartate, which is not a substrate for $P$. asaccharolyticus GDH, was also included in some initial rate measurements to determine whether, in assessing its contribution to the ionic strength, glutamate should be considered as mono- or trivalent at neutral $\mathrm{pH}$.

The standard assay mixture comprised $200 \mu \mathrm{M}-\mathrm{NAD}^{+}$and $50 \mathrm{mM}$-glutamate in $50 \mathrm{~mm}^{-}$ imidazole, pH 7. Fig. 7 shows the inhibitory effects of potassium phosphate upon the reaction, together with the effects of $\mathrm{K}^{+} \mathrm{Cl}^{-}$and several other ions. All ionic strengths were calculated from the relationship $\mu=1 / 2 \Sigma c z^{2}$, were $\mu$ is ionic strength, $c$ is molarity and $z$ is charge. Most of the salts seemed to exert a non-specific inhibition which depended on the value of $\mu$ and not on the chemical nature of the ions. However, phosphate was less inhibitory than the other ions tested. Enzyme activity declined rapidly with increasing $\mu$ up to a $\mu$ value of about 0.2 , at which it was about $10 \%$ of the control activity. Above $\mu=0.2$ there was a more gradual decline in activity.

Inhibition by both DL-aspartate and $\mathrm{K}^{+} \mathrm{Cl}^{-}$was competitive with respect to glutamate (see inset to Fig. 7). The dependence of DL-aspartate inhibition on the concentration of DL-aspartate suggested that the aspartate should be regarded as effectively singly-charged. Consequently, the net charge, and not the sum of the charges, on glutamate seems to be the most appropriate quantity to use in calculating its contribution to the ionic strength.

\section{DISCUSSION}

The modifications of the Whiteley (1957) growth medium adopted here resulted in high levels of a stable GDH in crude extracts of $\boldsymbol{P}$. asaccharolyticus, provided that harvesting was done at the correct time (Fig. 1). The single-step purification of GDH on Procion Orange MXG (and Blue PGR and Red MX-5B) linked to Sepharose 6B represents a major improvement over the methods already available. Furthermore, yields of more than $80 \%$ (and often $100 \%$ ) are obtained from these dye-columns.

The mode of adsorption of GDH onto the series of dye-columns was not highly specific (eight out of nine columns retained the enzyme); the three columns chosen were those that bound and 
released the fewest proteins in the same way as the GDH. The use of $\mathrm{pH}$ elution to resolve the GDH component further proved very successful.

The $P$. asaccharolyticus GDH is apparently hexameric, like several other bacterial GDHs (Smith et al., 1975). The coenzyme specificity has been resolved: both NADP ${ }^{+}$and NADPH are utilized at $4 \%$ of the rate for $\mathrm{NAD}^{+}$and $\mathrm{NADH}$, respectively, under the conditions used here. The $P$. asaccharolyticus GDH exhibits a much narrower amino acid specificity than oxliver GDH in that there is no counterpart to the 'alanine' activity. The utilization of several methylated analogues of glutamate by $P$. asaccharolyticus GDH is, however, similar to that of ox-liver GDH. Both enzymes seem to be unable to accommodate lateral substitutions as bulky as methyl groups, even when the dicarboxylate spacing is conserved. The rates of enzyme activity with $\mathrm{L}-\gamma$-methyleneglutamate are very low $(0.004 \%$ of the rate with glutamate at $\mathrm{pH} 7)$, implying that the presence of a double bond decreases the dicarboxylate spacing, rendering the substrate virtually inactive. However, $L-\alpha$-amino- $\gamma$-nitraminobutyrate is a reasonable replacement for glutamate, giving $4 \%$ of the glutamate activity at $\mathrm{pH} 7$, which suggests that the resultant distance between the two negative charges in this analogue must be close to $0.74 \mathrm{~nm}$, the correct dicarboxylate spacing (Caughey et al., 1957).

Potassium phosphate buffer $(0.2 \mathrm{M})$ minimized ionic interference and permitted easy estimation of kinetic parameters, without introducing any non-linearity. This buffer saturated the ionic effects of high glutamate (or 2-oxoglutarate and $\mathrm{NH}_{4} \mathrm{Cl}$ ) concentrations and thus proved suitable for kinetic studies.

We wish to thank the Science and Engineering Research Council in conjunction with Biozyme Laboratories for supporting this work through a CASE studentship to D. P. H. We are also grateful to Mr Paul E. Brown and $\mathrm{Mr}$ Peter Jackson for their capable technical help.

\section{REFERENCES}

BARKER, H. A. (1961). Fermentation of nitrogenous compounds. In The Bacteria, vol. 2, pp. 151-207. Edited by I. C. Gunsalus \& R. Y. Stanier. New York: Academic Press.

BARKER, H. A. (1981). Amino acid degradation by anaerobic bacteria. Annual Review of Biochemistry 50, 23-40.

BRADFORD, M. M. (1976). A rapid and sensitive method for the quantitation of microgram quantitites of protein using the principle of protein-dye binding. Analytical Biochemistry 72, 248-254.

BuCKeL, W. (1980). Analysis of the fermentation pathways of clostridia. Archives of Microbiology 127, 167-169.

BUCKEL, W. \& BARKER, H. A. (1974). Two pathways of glutamate fermentation by anaerobic bacteria. Journal of Bacteriology 117, 1248-1260.

Caughey, W. S., Smiley, J. D. \& Hellerman, L. (1957). L-Glutamic acid dehydrogenase: structural requirements for substrate competition: effect of thyroxine. Journal of Biological Chemistry 224, 591607.

DAviEs, B. J. (1964). Disc electrophoresis. II. Method of application to human serum proteins. Annals of the New York Academy of Sciences 121, 404-427.

Dean, P. D. G. \& Watson, D. H. (1979). Protein purification using immobilised triazine dyes. Journal of Chromatography 165, 301-319.

Dickinson, F. M. \& Engel, P. C. (1977). The preparation of pure, salt-free nicotinamide coenzymes. Analytical Biochemistry 82, 523-531.

Electricwala, A. H. \& Dickinson, F. M. (1979). Kinetic studies of dogfish liver glutamate dehydrogenase. Biochemical Journal 177, 449-459.
ENGel, P. C. \& Dalziel, K. (1969). Kinetic studies of glutamate dehydrogenase with glutamate and norvaline as substrates. Biochemical Journal 115, 621-631.

HEY, Y. \& DEAN, P. D. G. (1981). Dyes - a colourful approach to protein purification. Chemistry in Industry 20, 726-732.

Horler, D. F., Westlake, D. W. S. \& MCConnell, W. B. $(1966 a)$. Conversion of glutamic acid to volatile acids by Peptococcus aerogenes. Canadian Journal of Microbiology 12, 47-53.

Horler, D. F., MCCONnell, W. B. \& Westlake, D. W. S. $(1966 b)$. Glutaconic acid, a product of the fermentation of glutamic acid by Peptococcus aerogenes. Canadian Journal of Microbiology 12, 12471252.

HoRnBy, D. P. \& Engel, P. C. (1983). The coenzyme specificity of glutamate dehydrogenase from Peptococcus asaccharolyticus. Biochemical Society Transactions 11, 175-176.

Hornby, D. P., Engel, P. C. \& Hatanaka, S.-I. (1983). Beef liver glutamate dehydrogenase: a study of the oxidation of various alternative amino acid substrates retaining the correct spacing of the two carboxylate groups. International Journal of Biochemistry 15, 495-500.

HuCHO, F. \& JANDA, M. (1974). Investigation of the quaternary structure of beef liver glutamate dehydrogenase with bifunctional reagents. Biochemical and Biophysical Research Communications 57, 10801088.

Johnson, W. M. \& Westlake, D. W. S. (1972a). Alpha-ketoglutarate as an intermediate in glutamate metabolism by Peptococcus aerogenes. Canadian Journal of Microbiology 18, 875-880. 
Johnson, W. M. \& Westlake, D. W. S. (1972b). Purification and characterization of glutamic acid dehydrogenase and $\alpha$-ketoglutaric acid reductase from Peptococcus aerogenes. Canadian Journal of Microbiology 18, 881-892.

KEW, O. M. \& Woolfolk, C.A. (1970). Preparation of glutamate dehydrogenase from Micrococcus aerogenes. Biochemical and Biophysical Research Communications 39, 1126-1133.

LAEMMLI, U. K. (1970). Cleavage of structural proteins during the assembly of the head of bacteriophage T4. Nature, London 227, 680-685.

Lerud, R. \& Whiteley, H. R. (1971). Purification and properties of $\alpha$-ketoglutarate reductase from Micrococcus aerogenes. Journal of Bacteriology 106, 571577.

Markau, K. \& Steinhübel, I. (1972). Kinetic measurements with monocarboxylic acids as substrates and effectors of glutamate dehydrogenase. FEBS Letters 28. $115-120$.
Savada, K. V., ApPaji Rao, N. \& VenkitasubramanIAN, T. A. (1980). Isolation and characterisation of glutamate dehydrogenase from Mycobacterium smegmatis CDC 46. Biochimica et biophysica acta 615, 299-308.

Smith, E. L., Austen, B. M., Blumenthal, K. M. \& NYC, J. F. (1975). Glutamate dehydrogenases. In The Enzymes, 3rd edn, vol. 11, pp. 294-367. Edited by P. Boyer, New York: Academic Press.

Struck, J. \& Sizer, I. W. (1960). The substrate specificity of glutamic dehydrogenase. Archives of Biochemistry and Biophysics 86, 260-266.

Tномas, J. O. (1978). Determination of the subunit structure of proteins. In Techniques in Protein and Enzyme Biochemistry, part 1, no. B106, pp. 1-22. Edited by H. L. Kornberg, J. C. Metcalfe, D. H. Northcote, C. I. Pogson \& K. F. Tipton. Amsterdam: Elsevier/North Holland Press.

WhITELEY, H. R. (1957). Fermentation of amino acids by Micrococcus aerogenes. Journal of Bacteriology 74, 324-330. 